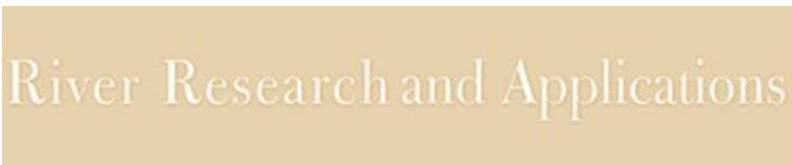

\title{
Responses of fishes and lampreys to the re-creation of meanders in a small English chalk stream
}

\begin{tabular}{|c|c|}
\hline Journal: & River Research and Applications \\
\hline Manuscript ID & RRA-16-0243.R2 \\
\hline Wiley - Manuscript type: & Research Article \\
\hline Date Submitted by the Author: & $\mathrm{n} / \mathrm{a}$ \\
\hline Complete List of Authors: & $\begin{array}{l}\text { Champkin, James; University College London, Department of Geography; } \\
\text { Centre for Environment Fisheries and Aquaculture Science, Salmon \& } \\
\text { Freshwater Team } \\
\text { Copp, Gordon; Cefas, Salmon \& Freshwater Team; Bournemouth } \\
\text { University, School of Conservation Sciences; Trent University, } \\
\text { Environmental and Life Sciences Graduate Program } \\
\text { Sayer, Carl; University College London, Department of Geography } \\
\text { Clilverd, Hannah; University College London, Department of Geography } \\
\text { George, Laura; University College London, Department of Geography } \\
\text { Vilizzi, Lorenzo; Uniwersytet Lodzki Instytut Ekologii i Ochrony Srodowiska, } \\
\text { Department of Ecology and Vertebrate Zoology } \\
\text { Godard, Michael; Centre for Environment Fisheries and Aquaculture } \\
\text { Science, Salmon \& Freshwater Team; AECOM Kitchener } \\
\text { Clarke, Jonathan; Environment Agency } \\
\text { Walker, Alan; Centre for Environment Fisheries and Aquaculture Science, } \\
\text { Salmon \& Freshwater Team }\end{array}$ \\
\hline Keywords: & $\begin{array}{l}\text { River Glaven, Brown trout, Brook lamprey, Restoration, Rehabilitation, } \\
\text { Floodplain connectivity }\end{array}$ \\
\hline
\end{tabular}

\section{SCHOLARONE \\ Manuscripts}


For consideration by River Research and Applications

1 Responses of fishes and lampreys to the re-creation of meanders in a

2 small English chalk stream

3

5 Godard $^{2,6}$, J. Clarke ${ }^{7}$ and A. M. Walker ${ }^{2}$

$6{ }^{1}$ Environmental Change Research Centre, Department of Geography, University College London,

7 Pearson Building, Gower Street, London, WC1E 6BT, UK

$8{ }^{2}$ Salmon and Freshwater Team, Centre for Environment, Fisheries and Aquaculture Science,

9 Lowestoft, Suffolk, NR33 OHT, UK

${ }^{3}$ Current address: The Angling Trust and Fish Legal, Eastwood House, 6 Rainbow Street,

Leominster, Herefordshire, HR6 8DQ, UK

${ }^{4}$ Centre for Conservation Ecology and Environmental Science, Bournemouth University, Poole, Dorset, UK

${ }^{5}$ Department of Ecology and Vertebrate Zoology, Faculty of Biology and Environmental Protection, Uniwersytet Łódzki, ul. Banacha 12/16, 90-237 Łódź, Poland

${ }^{6}$ Present address: AECOM, 50 Sportsworld Crossing Road, Unit 290, Kitchener, Ontario, N2P 0A4,

Canada

${ }^{7}$ Environment Agency, Dragonfly House, Norwich, UK

Correspondence to: G. H. Copp, Salmon and Freshwater Team, Centre for Environment, Fisheries and Aquaculture Science, Lowestoft, Suffolk, UK. Email: gordon.copp@cefas.co.uk

Running title: Fish and lamprey responses to stream rehabilitation work 
J. D. Champkin et al.

\section{Abstract}

River rehabilitation initiatives have become commonplace in European water courses as a result of European Union Water Framework Directive requirements. However, the short-term responses of fishes to such work have thus far been varied, with some river rehabilitation efforts resulting in demonstrable improvements in diversity and size structure whereas others have resulted in little or no change. Electrofishing and channel character surveys were conducted annually between 2009 and 2014 on a reach of the River Glaven (North Norfolk, UK) before and after rehabilitation work (embankment removal in 2009 and re-meandering in 2010) as well as on a control reach immediately upstream. To assess the effects of rehabilitation work, Before-After-Control-Impact (BACI) analysis tested for changes in channel character (geomorphology, substratum composition, meso-habitat structure) and in fish species richness, relative abundance, population density and size structure (calculated after fish data entry into the UK Environment Agency's National Fisheries Population Database). Following re-meandering work (i.e. treatment), habitat heterogeneity and depth variation increased in the treatment reach, but fish responses were not significant except for biomass and density increases of brown trout Salmo trutta, and abundance decreases of European eel Anguilla anguilla, in the treatment but not the control reach. These results are consistent with comparable river rehabilitation initiatives elsewhere, and they suggest that larger-scale rehabilitations are probably needed to produce greater increases in fish density and diversity. It is recommended that future rehabilitation initiatives address catchment-scale factors that can enhance ecosystem recovery, e.g. removal of barriers to colonization, increases in connectivity and water quality issues linked to eutrophication, elevated fine sediment inputs and various pollutants.

\section{KEYWORDS}

River Glaven, brown trout, brook lamprey, restoration, rehabilitation, floodplain connectivity 


\section{RIPARIAN REHABILITATION IMPACTS ON FISH SPECIES}

\section{$\begin{array}{lll}48 & 1 & \text { INTRODUCTION }\end{array}$}

Many European rivers have experienced progressive biodiversity homogenisation, dramatic changes in physical character as well as declines in chemical quality (e.g. Andrews, 1984; Brooker,

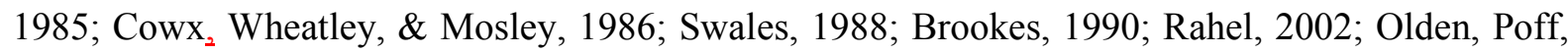
Douglas, Douglas, \& Fausch, 2004), which has increased their susceptibility to bioinvasions (Moyle, 1986; Ross, 1991; Poff \& Zimmerman, 2010). The Water Framework Directive (WFD; 2000/60/EC) obliges European Union (EU) member states to return, where feasible, water courses to 'Good Ecological Status' (European Parliament, 2000) and consequently the number of river rehabilitation initiatives has increased in recent decades. However, these efforts have not always resulted in beneficial changes in community composition and diversity (e.g. Pretty, Harrison, Shepherd, Smith, Hildred \& Hey, 2003; Harrison, Pretty, Shepherd, Hildred, Smith, \& Hey, 2004; Palmer, Menniger, \& Bernhardt, 2010; Hasse, Hering, Jähnig, Lorenz, \& Sundermann, 2013). Furthermore, in some cases, the work has inadvertently resulted in negative impacts on aquatic communities (e.g. Albertson, Cardinale, Zeug, Harrison, Leniham, \& Wydzga, 2010).

Fishes and lampreys have long been used as indicators of riverine ecosystem integrity (Karr, 1981), habitat quality (Barton, Taylor, \& Biette, 1985) and degradation (Fausch, Lyons, Karr, \& Angermeier, 1990), or as describers of riverine ecosystem function (Copp, 1989), and they are central to ecological status classifications for rivers and lakes under the WFD (Solimini, Cardoso, \& Heiskanen, 2006). Despite this, there are relatively few studies that have assessed the effects of river rehabilitation on fish assemblages (e.g. Swales \& O'Hara, 1983; Pretty et al., 2003; Roni, Bennett, Morley, Pess, Hanson, Slyke, \& Olmstead, 2006; Hasse et al., 2013), and the outcomes have largely been inconclusive. The weak response of fishes to in-stream rehabilitation work in low-gradient (lowland) streams could potentially be attributed to inappropriate designs and/or spatial scales (Pretty et al., 2003). Indeed, fish recovery following river rehabilitation may be hampered by catchment-scale factors, such as poor water quality or interrupted longitudinal connectivity due to water retention structures, which can limit re-colonization from downstream 
J. D. Champkin et al.

sources and isolate rehabilitated reaches within degraded river sections (Cowx et al., 1986; Pretty et al., 2003). Amongst the various issues worthy of consideration in this respect are the water course's current ecological status and its potential for enhancement (Brookes, 1990; Quinn \& Kwak, 2000).

Relatively un-impacted chalk rivers provide favourable conditions for diverse river macrophyte and faunal communities (Berrie, 1992) and represent priority ecosystems under the EU Habitats Directive (92/43/EEC). As low-energy systems, lowland rivers are not easily able to reinstate their original channel structure by natural means once it has been disturbed by engineering work (Sear et al., 2000). As such, river rehabilitation represents an important means of returning many chalk rivers to a more natural state and ecological function. The aim of the present Before-After-Control-Impact (BACI) study was to assess, based on six consecutive years of surveys (2009-2014), the initial responses of fishes and lampreys to re-meandering work implemented on a reach of the River Glaven, a small chalk stream in eastern England. Our specific objectives were to: 1) assess the physical changes in channel character (geomorphology, substratum composition, meso-habitat structure) resulting from the rehabilitation work; and 2) test for changes in fish species richness, relative abundance, population density and size structure. The null hypothesis was that the remeandering work would not result in a significant change in the diversity, density or size structure of the fish assemblage relative to before the rehabilitation work was undertaken.

\section{MATERIALS AND METHODS}

\subsection{Study area}

The River Glaven (Norfolk, UK) has chalk-dominated underlying geology in its middle-to-lower course and therefore is classed as a partial chalk stream (Pawley, 2008). Rising from headwaters near the village of Lower Bodham and dropping $50 \mathrm{~m}$ in altitude to its tidal limit at 'Cley next the Sea', the Glaven drains a relatively small coastal catchment $\left(a r e a=115 \mathrm{~km}^{2}\right)$ of mixed arable land (largely with agri-environment buffers) with coniferous/deciduous secondary woodland (upper and middle course), grazing meadows (middle course), and low-lying remnants of former estuarine marshland (lower course). The Glaven is alkaline ( $\mathrm{pH}$ 7.7-8.0) and moderately eutrophic, with 


\section{RIPARIAN REHABILITATION IMPACTS ON FISH SPECIES}

100 mean nitrate and phosphate concentrations of $6.2 \mathrm{mg} \mathrm{NO}_{3}^{-} \mathrm{L}^{-1}$ and $0.1 \mathrm{mg} \mathrm{P} \mathrm{L}^{-1} \mathrm{mg} \mathrm{L}^{-1}$,

101

102

103

104

105

106

107

108

109

110

111

112

113

114

115

116

117

118

119

120

121

122

123

respectively (Clilverd, Thompson, Heppell, Sayer, \& Axmacher, 2013). At Hunworth, mean annual river discharge from 2001 to 2010, measured at Environment Agency gauging station No. 034052, was $0.26 \mathrm{~m}^{3} \mathrm{~s}^{-1}\left(\min -\max =0.10-3.23 \mathrm{~m}^{3} \mathrm{~s}^{-1}\right)$, with lower discharge evident in summer compared to winter (Clilverd, Thompson, Heppell, Sayer, \& Axmacher,, 2016).

Historically, much of the Glaven has suffered from human-driven degradation due to: (i) straightening, deepening and relocation of the channel; (ii) interruption of longitudinal connectivity through the introduction of mills (five in total) and their associated mill ponds; (iii) removal of woody debris and in-stream vegetation through routine channel maintenance; and (iv) embankments (of $0.4 \mathrm{~m}$ to $1.1 \mathrm{~m}$ height above the meadow ground level) for flood defence, and thus isolation from its natural flood plain (Clilverd et al., 2013). Such modifications to the Glaven's natural geomorphology and hydrological regime are assumed to have negatively impacted on the river's biota, and in particular fish populations, primarily through reduced habitat heterogeneity and connectivity.

The study area included two reaches of the Glaven, one immediately upstream and one immediately downstream of Hunworth Bridge (a disused railway line; Figure 1). These stream reaches are known to support several species of conservation concern, including brook lamprey Lampetra planeri, European eel Anguilla anguilla, European bullhead Cottus gobio, white-clawed crayfish Austropotamobius pallipes and Eurasian otter Lutra lutra, all of which are listed in Annex II of the European Habitats Directive (92/43/EEC of 21 May 1992) as warranting protection. Also present were wild brown trout Salmo trutta (sustained only by natural recruitment with the nearest stocking taking place $\approx 7 \mathrm{~km}$ downstream at Glandford Mill, below three man-made barriers) and water vole Arvicola amphibious, which are listed as UK Biodiversity Action Plan (BAP) priority species (JNCC, 2013). 
J. D. Champkin et al.

124

125

126

127

128

Rehabilitation works in the 'treatment' study reach $(\approx 370 \mathrm{~m}$ length $)$ at Hunworth $\left(52.882152^{\circ} \mathrm{N}\right.$, $1.0658938^{\circ} \mathrm{E}$; elevation $\approx 20 \mathrm{~m}$; Figure 1) included embankment removal in March 2009 to reconnect the river with its flood plain (Clilverd et al., 2013, 2016; Figure 2b), followed in August 2010 by the re-creation of meanders to increase channel sinuosity and instream habitat heterogeneity (Figure 1; Figure 2c). Additionally, six parapotamon-type backwaters (sensu Amoros, Rouz, Reygrobellet, Bravard, \& Pautou, 1987) of 3-18 m length were created from the remnants of the former river channel (Sayer, 2014; Figure 1). The connectivity to the main channel of these lentic, re-established former meanders varied temporally; with progressive siltation of their downstream confluence with the main channel, they quickly became increasingly isolated and connected to the main channel during periods of elevated discharge only. The bare soil on the river banks was left to natural plant re-colonisation except for the planting of a few small patches of locally sourced reed sweet-grass (Glyceria maxima) to help stabilise the newly-created meanders. A reach of $160 \mathrm{~m}$ length, situated immediately upstream of the impact reach, acted as a 'control' - the control reach was not identical to the impact reach, but it was the closest available reach for which landowner permission could be obtained to include in the study and sufficiently similar for use as a control.

\subsection{Geomorphology, discharge, substratum and fish surveys}

Cross-sections of the stream channel and embankments were surveyed three times using a differential Global Positioning System (dGPS; Leica Geosystems SR530 base station receiver and Series 1200 rover receiver, Milton Keynes, UK): in April 2008, prior to embankment removal; in July 2009, after embankment removal; and in September 2010, after meander creation. Each survey was conducted using the survey pole in static mode, which resulted in a $3 \mathrm{D}$ coordinate quality of $1-$ $2 \mathrm{~cm}$ (Clilverd et al., 2013). A new stream outline for the re-meandered channel was surveyed at intervals of $<1 \mathrm{~m}$, and redrawn in Arc-GIS software. Channel length before and after remeandering, as well as longitudinal length used in the calculation of river sinuosity, were measured in Arc-GIS with the "Measure Line" tool. Stream surface area was measured in Arc-GIS using the 


\section{RIPARIAN REHABILITATION IMPACTS ON FISH SPECIES}

150 "Measure Polygon Feature" tool. Substratum composition was surveyed visually, one year prior to

151

152

153

154

155

156

157

158

159

160

161

162

163

164

165

166

167

168

169

170

171

172

173

174

(i.e. 2009) and two years after (i.e. 2012) the re-creation of meanders, using a bathyscope at $\approx 3-5 \mathrm{~m}$ intervals with three categories (silt and sand; gravel; cobble) and estimated to the nearest $5 \%$. Water depth (to nearest $\mathrm{cm}$ ) was measured using a metre rule at three positions across each transect (channel midpoint, and at $\approx 30 \mathrm{~cm}$ from water's edge on each bank). Meso-habitats in the form of physical biotopes were recorded by walking the river reaches and estimating presence using criteria as per Newson and Newson (2000) to define physical biotopes.

Fish assemblage surveys of the treatment and control reaches were undertaken on eight occasions during 2009-2014: i) on 27 February and 5 March 2009, both prior to embankment removal; ii) on 3 and 4 June 2009 after embankment removal; iii) on 24 and 25 June 2010, about five weeks prior to meander creation; iv) on 3 August 2010 as a fish rescue operation just prior to meander creation; and then v) annually in late May or early June from 2011 to 2014, inclusive. On each sampling occasion, the treatment and control reaches were sampled, normally on consecutive days (downstream reach, then upstream reach), by blocking off the up- and downstream extents with stop nets ( $8 \mathrm{~mm}$ mesh size), followed by continuous electrofishing (230 V Electracatch control box, $50 \mathrm{~Hz}$ pulsed direct current, $2 \mathrm{~m}$ twin-tailed cathode): two persons fishing each with a $400 \mathrm{~mm}$ circular anode and a hand net (mesh size $=8 \mathrm{~mm}$ at bottom, $10-12 \mathrm{~mm}$ sides). As per DeLury (1951), three successive downstream-to-upstream electrofishing runs were completed through the study reach using a consistent level of fishing effort. During each run, fish were removed to aerated tanks, identified to species, counted, and measured for total length (TL; nearest $1 \mathrm{~mm}$ ) and weight (nearest $1 \mathrm{~g}$ for large fishes, $0.1 \mathrm{~g}$ for smaller specimens). Anquilla anguilla and L. planeri specimens, which were sedated under UK Home Office licence using a mild anaesthetic $\left(0.5 \mathrm{~mL} \mathrm{~L}^{-1}\right.$ of 2-phenoxy ethanol) to facilitate measurements, were allowed to recover fully in fresh water prior to release back to their stream of capture along with other processed fishes after the third sampling run. 
J. D. Champkin et al.

175

176

177

178

179

180

181

182

183

184

185

186

187

\subsection{Statistical analyses}

Data were analysed based on a BACI experimental design, with consideration of multiple sampling occasions (Smith, 2002). Three 'before' and four 'after' sampling events were available and analyses focused on species-specific fish abundance, TL, weight, biomass and density estimates ( $95 \%$ confidence limits), which for consistency (i.e. comparability of the estimates) were calculated using the Environment Agency (EA) National Fisheries Population Database, as per the Carle \& Strub (1978) population model. Data on fishes and L. planeri rescued during the re-meandering works were collected in a manner not comparable with the other sampling excursions, so these data were excluded from all analyses. The EA National Fisheries Population Database does not contain a length-weight relationship for $L$. planeri, so biomass and density estimates could not be calculated for that species. Biological diversity indices were not tested because the same five species predominated in the treatment and control reaches prior to and following re-meandering.

By definition, in a BACI design the effect of interest is the Site $\times$ Period interaction term. The marginal mean $(\mu)$ values, i.e. the means for each factor (site) averaged across all levels of that factor (sampling periods), were used indirectly to estimate the strength of the BACI contrast as:

$$
\text { BACI effect }=\mu C A-\mu C B-\mu T A+\mu T B
$$

where $C A$ is the control site following intervention (i.e. rehabilitation); $C B$ is the control site prior to intervention; $T A$ is the treatment site after intervention; and $T B$ is the treatment site before intervention (Schwartz, 2014). Accordingly, a significant effect will occur if a change in any of the species-specific response variables is detected at the rehabilitation site following intervention relative to the control site. Notably, (pseudo)replicates at the site level (i.e. TL and weight of fishes obtained from the three electrofishing runs) were averaged over as 'quadrat-to-quadrat' variation (Schwartz, 2014).

BACI statistical analyses followed the protocols outlined in Schwartz (2014) and were implemented in R (R Core Team, 2014). However, given the relatively limited number of replicate 


\section{RIPARIAN REHABILITATION IMPACTS ON FISH SPECIES}

200

201

202

203

204

205

206

207

208

209

210

211

212

213

214

215

216

217

218

219

220

221

222

223

224

samples (i.e. electrofishing runs), the potential interdependence of the control and treatment reaches, and sampling events resulting from 'real-world' experimental constraints, tests of significance were carried out at $\alpha=0.10$ for heuristic purposes (Kline, 2013) and followed throughout the more flexible Fisherian interpretation of significance testing as opposed to the stricter Neyman-Pearsonian approach (Oakes, 1986). Tests for changes in water depth and substrata following rehabilitation were evaluated using analysis of variance (ANOVA) tests applied to mixed-effect linear models, whereas changes in meso-habitat presence were evaluated using onesample Chi-squared $\left(\chi^{2}\right)$ tests.

\section{$3 \quad$ RESULTS}

\subsection{Changes in channel geomorphology}

The creation of meanders increased channel length in the treatment reach from $370 \mathrm{~m}$ to $430 \mathrm{~m}$ and decreased mean channel width by about $0.5 \mathrm{~m}$ (from $\approx 3.2 \pm 0.4 \mathrm{~m}$ SE to $\approx 2.7 \pm 0.5 \mathrm{~m}$ ), resulting in an increase in channel surface area of $407 \mathrm{~m}^{2}$ (from 1549 to $1956 \mathrm{~m}^{2}$ ). Concurrently, substratum changed between 2009 and 2012, with silt decreasing by $>14 \%\left(F_{1,155}=14.49, P<0.001\right)$ whilst gravel increased by $>13 \%\left(F_{1,155}=14.46, P<0.001\right)$; however, silt continued to comprise a high proportion $(>46 \%)$ of the substratum in the treatment reach following the rehabilitation work (Figure 3a). There was no change in the proportion of cobbles $\left(F_{1,155}=1.18, P>0.2\right.$; Figure $\left.3 \mathrm{a}\right)$. An increasing trend in mean water depth, from $30.0 \pm 1.15 \mathrm{~cm}(n=52)$ to $33.5 \pm 1.95 \mathrm{~cm}(n=65)$ was not statistically significant $\left(F_{1,51}=2.34, P>0.1\right)$, but depth variability increased from $10-52 \mathrm{~cm}$ to 12-74 cm post-rehabilitation, coinciding with an increased number of deeper pool biotopes (Figure 3c; one-sample $\chi^{2}$ test, $P<0.05$ ). Riffle habitat remained rare (Figure $3 \mathrm{c}$ ). Thus, the recreation of meanders and additional pools likely increased hydraulic and habitat heterogeneity throughout the treatment reach, including flow refugia.

In the control reach, substratum composition did not change before and after the downstream rehabilitation work (ANOVAs, all $P$-values $>0.05$; Figure $3 \mathrm{~b}$ ), but mean water depth declined by $\approx$ 
J. D. Champkin et al.

$22523 \%$ in the control reach, from $24.1 \pm 2.2 \mathrm{~cm}$ in $2009(n=22)$ to $18.4 \pm 1.5 \mathrm{~cm}$ in $2012(n=27$;

226

227

228

229

230

231

232

233

234

235

236

237

238

239

240

241

242

243

244

245

246

247

248

$\left.F_{1,21}=5.78, P<0.05\right)$ - this was due to seasonal differences in stream discharge (Clilverd et al., 2016) as well as reduced discharge in those years rather than to the downstream re-meandering work (Environment Agency, unpublished data). Biotope proportions also varied with the incidence of riffle meso-habitats declining and the frequency of runs increasing after the downstream rehabilitation work (Fig 3; one-sample $\chi^{2}$ test, $P<0.05$ ). However, the prevalence of glides or pools remained unchanged (Figure $3 \mathrm{~d}$; one-sample $\chi^{2}$ test, both $P$ values $>0.05$ ).

\subsection{Effects on fish assemblage structure}

In total, 8864 specimens of six fish and one lamprey species were captured during the study (Table 1). Of these, five species were dominant (\% of catch) in the assemblage throughout both reaches: $C$. gobio $(55 \%)$ and L. planeri $(25 \%)$ were most abundant, followed by S. trutta (8\%), threespine stickleback Gasterosteus aculeatus (5.9\%) and A. anguilla (5.5\%). Also captured were northern pike Esox lucius $(0.2 \%)$ and tench Tinca tinca $(<0.1 \%)$ but in too low relative abundance $(<5 \%)$ for inclusion in the BACI analyses.

A statistically significant BACI effect was detected for $A$. anguilla abundance (number of individuals) and for S. trutta mean weight and biomass (Figure 4). Specifically, A. anguilla numerical abundance decreased in the treatment reach following rehabilitation work $(n=27 \pm 4)$ relative to pre-intervention conditions $(n=75 \pm 5)$, but this decrease was within the context of a decreasing trend in the control reach as well. For $S$. trutta, there was an increase in the treatment reach following rehabilitation work in both weight $(\mathrm{Wt}=96.8 \pm 12.4 \mathrm{~g})$ and biomass $(\mathrm{SC}=462.9 \pm$

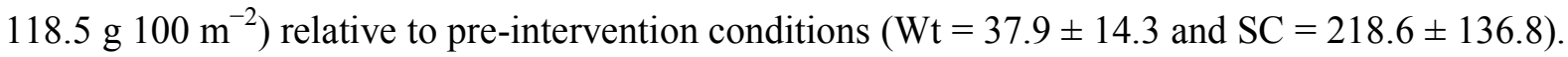
By contrast, no significant change was observed amongst the above response variables in the control reach for either $A$. anguilla $(n$ before $=35 \pm 5$ vs. $n$ after $=12 \pm 4)$ or $S$. trutta $($ Wt before $=$ $34.9 \pm 14.3 v s . \mathrm{Wt}$ after $=50.6 \pm 12.4 ; \mathrm{SC}$ before $=365.3 \pm 136.8 v s . \mathrm{SC}$ after $=300.6 \pm 118.5)$. 


\section{RIPARIAN REHABILITATION IMPACTS ON FISH SPECIES}

\section{DISCUSSION}

250 The River Glaven Rehabilitation Project was successful in increasing hydromorphological 251 variability, water depth, substratum diversity and habitat heterogeneity in the re-meandered reach. 252 With the observed significant increase in pool habitat availability (Figure 3c), there was a 253 corresponding significant increase in the mean weight and biomass of $S$. trutta. This can be 254 explained either by an immigration of larger individuals from outside the re-meandered reach, or 255 the enhanced growth of pre-existing $S$. trutta due to a more favourable environment, or (given that 256 S. trutta abundance did not change significantly) smaller individuals migrated (or were forced) out 257 of the re-meandered reach. A similar increase in mean $S$. trutta size was achieved in a rehabilitation 258 initiative of the White River, Arkansas, USA (Quinn \& Kwak, 2000). Larger individuals of S. trutta 259 and other salmonids are well known to prefer deeper pools within streams that comprise a diversity 260 of meso-habitats (Bohlin, 1977; Kennedy \& Strange, 1982; Crisp, 1996; Armstrong, Kemp, 261 Kennedy, Ladle, \& Milner, 2003; Stakènas, Vilizzi, \& Copp, 2013). Deeper pools provide better 262 refuge and overwintering habitat for larger fishes, resulting in the "bigger fish - deeper habitat" 263 relationship (Maki-Petäys, Muotka, Huusko, Tikkanen, \& Kreivi, 1997). In addition, a shortage of 264 deeper pool habitat can impose a recruitment bottleneck in large-bodied riverine fishes (Persat, \& 265 Chessel, 1989).

Increased habitat heterogeneity, and specifically riffle-deep pool sequences, is a common objective of rehabilitation work regardless of its scale, and trout species commonly respond positively to such outcomes. For example, in a study of in-stream rehabilitation in Liechtenstein, which aimed to improve salmonid habitat in channelized streams (Zika \& Peter, 2002), woody debris was felled into the river channel and this led to increased mean water depth, with subsequent increases in the numerical abundance and biomass of both $S$. trutta and rainbow trout Oncorhynchus mykiss. A similar increase in large (adult) S. trutta abundance was observed in several reaches of the River Piddle and Devil's Brook (Dorset, England), where rehabilitation work involved pool excavation and fencing to impede bankside erosion by livestock (Summers, Giles, \& 


\section{River Research and Applications}

J. D. Champkin et al.

275 Stubbing, 2008). Overall, the majority of in-stream habitat improvement strategies aimed at

276

277

278

279

280

281

282

283

284

285

286

287

increasing salmonid (trout) populations seem to have negligible effects on juvenile fish but frequently succeed in increasing the relative abundance of larger adults (e.g. Summers et al., 2008;

Louhi, 2010).

Increased habitat heterogeneity and changes in fish abundance are not always achieved in rehabilitated river reaches. For instance, little change was observed in fish species composition following the removal of two small weirs on the River Dove, Derbyshire, UK, channel narrowing on Lowthorpe Beck, East Yorkshire, UK and the creation of gravel riffles on the River Stiffkey, North Norfolk, UK (Smith, 2013). Similarly, a study of 13 lowland streams subjected to rehabilitation work (Pretty et al., 2003) found little change in fish abundances, noting though that only two species $C$. gobio and stone loach Barbatula barbatula were present in sufficient numbers for analysis in their study. This is not surprising, as C. gobio is characteristic of (Copp, 1992) and often the dominate fish species in, stream fish assemblages in England (e.g. Carter, Copp, \& Szomolai, 2004; Nunn, Copp, Vilizzi \& Carter, 2010). Similarly, L. planeri can be quite abundant in small streams, such as observed here (Table 1) though temporally variable in number (e.g. Copp, Stakenas, \& Cucherousset, 2010), which is most likely due to the difficulty in surveying this benthic species (Harvey \& Cowx, 2003).

In the River Glaven, which is a contiguous catchment to the Stiffkey, the re-creation of meanders represented a much more comprehensive alteration of stream geomorphology, with a decrease in the frequency of riffles and an increase in run meso-habitats. However, no effect was observed on overall ichthyofauna composition nor on density or biomass except for S. trutta and A. anguilla abundance (Tables 1 and 2). This is not an isolated case, and numerous other studies have shown that stream rehabilitation does not necessarily translate into significant improvements in biotic communities, at least in the short term (e.g. Theiling, Tucket, \& Cronin, 1999; Pretty et al., 2003; Palmer et al., 2010; Hasse et al., 2013; Smith, 2013; Nilsson, Polvi, Gardeström, Hasselquist, Lind, \& Sarneel, 2014). This may be attributable to a combination of factors that cannot be addressed by 


\section{RIPARIAN REHABILITATION IMPACTS ON FISH SPECIES}

301 localised river rehabilitation work. One factor that is not addressed by reach-scale rehabilitation is

302

303

304

305

306

307

308

309

310

311 the influence of catchment-scale pressures on rivers, such as declines in water quality through eutrophication, sporadic organic and chemical pollution events, and enhanced fine sediment inputs (e.g. Johnes, 1996; Summers et al., 2008; Zięba, Stakėnas, Godard, Ives, Seymour, Carter, \& Copp, 2014). Such pressures are certainly relevant to the River Glaven, which drains a predominantly arable catchment with a number of small-scale sewage treatment works in its headwaters. Consequently, as suggested by Palmer et al. (2010), river rehabilitation efforts may be more effective if they concentrate on improving water quality within the upper stretches of small rivers in agricultural catchments to reduce stresses placed on downstream biological communities. A good example of this is the River Lee (or Lea), Hertfordshire (England), which is of relatively natural geomorphology (especially the upper half of its course; Scarlett \& O'Hare, 2006). However, a domestic wastewater treatment plant near its source exerts a strong influence on the river's discharge regime and water quality (Faulkner \& Copp, 2001; Pilcher, Copp, \& Szomolai, 2004), and these upstream pressures would need to be mitigated to achieve substantial overall habitat improvements to permit the return of salmonid species known historically to inhabit the river's upper courses (Herts and Middlesex Wildlife Trust, 2015).

River rehabilitation work can also fail to address broader-scale species-specific pressures, emphasising the need for the spatial scale of the rehabilitation work to be proportional to system size (Schmutz, Kremser, Melcher, Jungwirth, Muhar, Waidbacher, \& Zauner, 2014) and to the specific causes of river degradation. For example, the recruitment of $A$. anguilla has declined throughout its range in recent decades (Moriarty, 1986; ICES, 2016), including in our study area (Almeida, Copp, Masson, Miranda, Murai, \& Sayer, 2012), due to a variety of factors (Feunteun, 2002; Starkie, 2003; Van Ginneken \& Maes, 2005; Friedland, Miller, \& Knights, 2007). In addition to the stock-wide decline in recruitment to continental waters, an additional key aspect is reduced elver recruitment within river systems, where water retention structures represent barriers to 
J. D. Champkin et al.

migration, and unless these barriers are removed or their effect mitigated (e.g. through fish passage solutions), local habitat enhancement measures are unlikely to improve the recruitment of $A$. anguilla populations in affected water courses. Indeed, a key aim of river rehabilitation programmes is to recreate the natural hydrological and geomorphological dynamics along the longitudinal and lateral (floodplain) dimensions of a river system (e.g. Copp, 1991; Kemp, Harper, \& Crosa, 1999), as actions in any one reach will have knock-on consequences in both upstream and downstream directions, but increased fish recruitment is necessary at some point in time to take advantage of improved habitat with increased productive capacity.

There is clearly great potential for in-stream habitat improvement in river rehabilitation projects, and there are undoubtedly a great many modified reaches of small water courses within which the degraded biotic communities would benefit significantly from habitat enhancement. It is important, however, that river rehabilitation initiatives target water courses (or sections thereof) where rehabilitation efforts would result in the greatest ecological benefit. In this respect, reaches with altered geomorphology but improving water quality and/or connectivity could be of high priority. Recommended steps prior to the allocation of scarce financial resources available for river rehabilitation schemes (Brookes, 1990; Quinn \& Kwak, 2000) include: i) systematic and carefullyplanned preliminary biological surveys of in-stream and riparian communities of river systems, ii) consideration of historical, long-term fish survey data where possible to put impacts into context (e.g. Zięba et al., 2014), and iii) attention to both longitudinal and lateral connectivity for fishes and lampreys (Hohausová, Copp, \& Jankovský, 2003; Nunn et al., 2010). Some water courses have undergone considerable modification but have nonetheless been able to sustain threatened species and associated high level of biological diversity - the case in point here is the River Glaven at Hunworth. Indeed, information from preliminary surveys and previous biological monitoring should be fed into ecosystem assessments to establish whether the flora and fauna have the potential for increased density or richness (Pretty et al., 2003). 


\section{ACKNOWLEDGEMENTS}

354 We thank the Stody Estate for access to the study site and N. Beardmore, H. Beardsley, R. 355 Bucknell, M. Chadwick, D. Emson, G. Gamble, T. Howard, H. Mandley, H. Packer, P. Rosewarne, 356 M. Rylands, J. Tosney, M. Ward and G. Zięba, for assistance with field sampling. The Wild Trout 357 Trust, Norfolk Wildlife Trust, Natural England, R. D. Hey and the River Glaven Conservation 358 Group facilitated the river rehabilitation work.

\section{REFERENCES}

360

361

362

363

364

365

366

367

368

369

370

371

372

373

374

Albertson, L. K., Cardinale, B. J., Zeug, S. C., Harrison, L. R., Leniham, H. S., \& Wydzga, M. A. (2010). Impacts of channel reconstruction on invertebrate assemblages in a restored river. Restoration Ecology, 19, 637-638.

Almeida, D., Copp, G. H., Masson, L., Miranda, R., Murai, M., \& Sayer, C. D. (2012). Changes in the diet of a recovering Eurasian otter population between the 1970s and the 2010s. Aquatic Conservation: Marine and Freshwater Ecosystems, 22, 26-35.

Amoros, C., Roux, A.-L., Reygrobellet, J.-L., Bravard, J.-P., \& Pautou, G. (1987). A method for applied ecological studies of fluvial hydrosystems. River Research and Applications, 1(1), 1736.

Andrews, M. J. (1984). Thames estuary: pollution and recovery. In P. J. Sheehan, D. R. Miller, G. C. Butler, \& P. Bourdeau (Eds). Effects of pollutants at the ecosystem level. (SCOPE: Chapter 7, 195-227). London: Wiley \& Sons.

Armstrong, J. D., Kemp, P. S., Kennedy, G. J. A., Ladle, M., \& Milner, N. J. (2003). Habitat requirements of Atlantic salmon and brown trout in rivers and streams. Fisheries Research, 62, $143-170$. 
J. D. Champkin et al.

375 Barton, D. R., Taylor, W. D., \& Biette, R. M. (1985). Dimensions of riparian buffer strips required

376

377

378

379

380

381

382

383

384

385

386

387

388

389

390

391

392

393

394

395

396

397

398 to maintain trout habitat in Southern Ontario streams. North American Journal of Fisheries Management, 5, 364-378.

Berrie, A. D. (1992). The chalk-stream environment. Hydrobiologia, 248, 3-9.

Bohlin, T. (1977). Habitat selection and intercohort competition of juvenile sea-trout Salmo trutta. Oikos, 29, 112-117.

Brooker, M. P. (1985). The ecological effects of channelization. The Geographical Journal, 151, 63-69.

Brookes, A. (1990). Restoration and enhancement of engineered river channels: some European experiences. Regulated Rivers: Research and Management, 5, 45-56.

Carle, F. L., \& Strub, M. R.,. (1978). A method for estimating population size from removal data. Biometrics, 34, 621-630.

Carter, M. G., Copp, G. H., \& Szomolai, V. (2004). Seasonal abundance and microhabitat use of bullhead Cottus gobio and accompanying fish species in the River Avon (Hampshire), and implications for conservation. Aquatic Conservation: Marine \& Freshwater Ecosystems, 14, $395-412$.

Clilverd, H. M., Thompson, J. R., Heppell, C. M., Sayer, C. D., \& Axmacher, J. C. (2013). Riverfloodplain hydrology of an embanked lowland Chalk river and initial response to embankment removal. Hydrological Sciences Journal, 58, 627-650.

Clilverd, H. M., Thompson, J. R., Heppell, C. M., Sayer, C. D., \& Axmacher, J. C. (2016). Coupled hydrological/hydraulic modelling of river restoration impacts and floodplain hydrodynamics. River Research and Applications, 32, 1927-1948.

Copp, G. H. (1989). The habitat diversity and fish reproductive function of floodplain ecosystems. Environmental Biology of Fishes, 26, 1-26. 


\section{RIPARIAN REHABILITATION IMPACTS ON FISH SPECIES}

399 Copp, G. H. (1991). Typology of aquatic habitats in the Great Ouse, a small regulated lowland $400 \quad$ river. Regulated Rivers: Research \& Management, 6, 125-134.

401 Copp, G. H. (1992). An empirical model for predicting the microhabitat of 0+ juveniles in lowland $402 \quad$ streams. Oecologia, 91, 338-345.

403

404

405

406

407

408

409

410

411

412

413

414

415

416

417

418

419

420

421

422

Copp, G. H., Stakènas, S., \& Cucherousset, J. (2010). Aliens vs. the natives: interactions between introduced Lepomis gibbosus and indigenous Salmo trutta in small streams of southern England. In K. B. Gido, \& D. Jackson (Eds.), Community ecology of stream fishes: Concepts, approaches and techniques (pp. 347-370). Bethesda, Maryland: American Fisheries Society.

Cowx, I. G., Wheatley, G. A., \& Mosley, A. S. (1986). Long-term effects of land drainage works on fish stocks in the upper reaches of a lowland river. Journal of Environmental Management, 22, 147-156.

Crisp, D. T. (1996). Environmental requirements of common riverine European salmonid fish species in fresh water with particular references to physical and chemical aspects. Hydrobiologia, 323, 201-221.

DeLury, D. B. (1951). On the planning of experiments for the estimation of fish populations. Journal of the Fisheries Research Board of Canada, 8, 281-307.

Everard, M. (2012). Why does 'good ecological status' matter? Water and Environment Journal, $26,165-174$.

Faulkner, H., \& Copp, G. H. (2001). A model for accurate drift estimation in streams. Freshwater Biology, 46, 723-733.

Fausch, K.D., Lyons, J., Karr, J. R., \& Angermeier, P. L. (1990). Fish communities as indicators of environmental degradation. American Fisheries Society Symposium, 8, 123-144.

Feunteun, E. (2002). Management and restoration of European eel population (Anguilla anguilla): An impossible bargain. Ecological Engineering, 18, 575-591. 
J. D. Champkin et al.

423 Friedland, K. D., Miller, M. J., \& Knights, B. (2007). Oceanic changes in the Sargasso Sea and

424

425

426

427

428

429

430

431

432

433

434

435

436

437

438

439

440

441

442

443

444

445

446

447 declines in recruitment of the European eel. ICES Journal of Marine Science, 64, 519-530.

Harrison, S. S. C., Pretty, J. L., Shepherd. D., Hildrew, A. G., Smith, C., \& Hey, R. D. (2004). The effect of instream rehabilitation structures on macroinvertebrates in lowland rivers. Journal of Applied Ecology, 41, 1140-1154.

Harvey, J., \& Cowx, I. G. (2003). Monitoring the river, brook and sea lamprey, Lampetra fluviatilis, L. planeri and Petromyzon marinus. Conserving Natura 2000 Rivers Monitoring Series No. 5, Peterborough: English Nature.

Hasse, P., Hering, D., Jähnig, S. C., Lorenz, A. W., \& Sundermann, A. (2013). The impact of hydromorphological restoration on river ecological status: a comparison of fish, benthic invertebrates and macrophytes. Hydrobiologia, 704, 475-488.

Helfied, J. M., Capon, S. J., Nilsson, C., Jansson, R., \& Palm, D. (2007). Restoration of rivers used for timber floating: effects on riparian plant diversity. Ecological Applications, 17, 840-851.

Hohausová, E., Copp, G. H., \& Jankovský, P. (2003). Movement of fish between a river and its backwater: diel activity and relation to environmental gradients. Ecology of Freshwater Fishes, $12,107-117$.

Nunn, A. D., Copp, G. H., Vilizzi, L., \& Carter, M. G. (2010). Seasonal and diel patterns in the migration of fishes between a river and a floodplain tributary. Ecology of Freshwater Fishes, 19, $153-162$.

ICES. (2016). European eel (Anguilla anguilla) throughout its natural range. ICES Advice on fishing opportunities, catch, and effort, Northeast Atlantic, ICES Advice 2016, Book 9, Published 28 October 2016.

Johnes, P. J. (1996). Evaluation and management of the impact of land use change on the nitrogen and phosphorus load delivered to surface waters: the export coefficient modelling approach. Journal of Hydrology, 183, 323-349. 


\section{RIPARIAN REHABILITATION IMPACTS ON FISH SPECIES}

448 Joint Nature Conservation Committee (JNCC). (2013). The UK Approach to Assessing 449 Conservation Status for the EA Habitats Directive Article 17 Reporting. JNCC, Peterborough. 450 Karr, J. R. (1981). Assessment of biotic integrity using fish communities. Fisheries, 6(6), 21-27. 451 Kemp, J. L., Harper, D. M., \& Crosa, G. A. (1999). Use of 'functional habitats' to link ecology with 452 morphology and hydrology in river rehabilitation. Aquatic Conservation: Marine and $453 \quad$ Freshwater Ecosystems, 9, 159-178.

454 455 456 457 458 459

460

461

462

463

464 465 466 467

Kennedy, G. J. A., \& Strange, C. D. (1982). The distribution of salmonids in upland streams in relation to depth and gradient. Journal of Fish Biology, 20, 579-591.

Kline, R. B. (2013). Beyond significance testing: Statistics reform in the behavioral sciences. 2nd Edn., Washington D. C.: American Psychological Association. 328 pp.

Louhi, P. (2010). Responses of brown trout and benthic invertebrates to catchment-scale disturbance and in-stream restoration measures in boreal river systems. Dissertation, University of Oulu, Finland.

Maki-Petäys, A., Muotka, T., Huusko, A., Tikkanen, P., \& Kreivi, P. (1997). Seasonal changes in habitat use and preference by juvenile brown trout, Salmo trutta, in a northern boreal river. Canadian Journal of Fisheries and Aquatic Science, 54, 520-530.

Moriarty, C. (1986). Variations in elver abundance at European catching stations from 1958 to 1985. Vie et Milieu, 36, 233-235.

Moyle, P. B. (1986). Fish introductions into North America: patterns and ecological impact. In H. A. Mooney, \& J. A. Drake (Eds.), Ecology of biological invasion of North America and Hawaii. Ecological Studies 58. New York: Springer-Verlag; 27-43.

Newson, M., \& Newson, C. (2000). Geomorphology, ecology and river channel habitat: mesoscale approaches to basin-scale challenges. Progress in Physical Geography, 24, 195-217. 
J. D. Champkin et al.

471 Nilsson, C., Polvi, L. E., Gardeström, J., Hasselquist, E. M., Lind, L., \& Sarneel, J. M. (2014).

472

473

474

475

476

477

478

479

480

481

482

483

484

485

486

487

488

489

490

491

492

493

494 Riparian and in-stream restoration of boreal streams and rivers: success of failure? Ecohydrology, 8, 753-764.

Oakes, M. (1986). Statistical Inference: A commentary for the social and behavioural sciences. New York: Wiley \& Sons. 196 p.

Olden, J. D., Poff, N. L., Douglas, M. R., Douglas, M. E., \& Fausch, K. D. (2004). Ecological and evolutionary consequences of biotic homogenization. Trends in Ecology and Evolution, 19, 1824.

Palmer, M. A., Menniger, H. L., \& Bernhardt, E. (2010). River restoration, habitat heterogeneity and biodiversity: a failure of theory or practice? Freshwater Biology, 55, 205-222.

Pawley, S. M. (2008). The Glaven Valley (Glandford Quarry) (TG 055415). In: Candy I, Lee R, Harrison AM, eds. The Quarternary of Northern East Anglia. Devon: Quarternary Research Association; 192-203.

Persat, H., \& Chessel, D. (1989). Typologie de distributions en classes de taille : intérêt dans l'étude des populations de poissons et d'invertébrés. Acta Ecologica, Ecologia Generalis, 10, 175195.

Pilcher, M., Copp, G. H., \& Szomolai, V. (2004). A comparison of adjacent natural and channelised stretches of a lowland river. Biologia-Bratislava, 59, 669-673.

Poff, N. L., \& Zimmerman, J. K. H. (2010). Ecological responses to altered flow regimes: a literature review to inform the science and management of environmental flows. Freshwater Biology, 55, 194-205.

Pretty, J. L., Harrison, S. S. C., Shepherd, D. J., Smith, C., Hildrew, A. G., \& Hey, R. D. (2003). River rehabilitation and fish populations: assessing the benefit of instream structures. Journal of Applied Ecology, 40, 251-265. 


\section{RIPARIAN REHABILITATION IMPACTS ON FISH SPECIES}

495 Quinn, J. W., \& Kwak, T. J. (2000). Use of rehabilitated habitat by brown trout and rainbow trout in 496 an Ozark tailwater river. North American Journal of Fisheries Management, 20, 737-751.

497 R Core Team. (2014). R: A language and environment for statistical computing. R Foundation for 498 Statistical Computing, Vienna, Austria. (www.R-project.org/).

499

500

501

502

503

504

505

506

507

508

509

510

511

512

513

514

515

516

517

Rahel, F. J. (2002). Homogenization of fish faunas. Annual Reviews of Ecology and Systematics, $33,291-315$.

Roni, P., Bennett, T., Morley, S., Pess, G. R., Hanson, K., Slyke, D. V., \& Olmstead, P. (2006). Rehabilitation of bedrock stream channels: the effects of boulder weir placement on aquatic habitat and biota. Research and Applications, 22, 967-980.

Ross, S. T. (1991). Mechanisms structuring stream fish assemblages: are there lessons from introduced species? Environmental Biology of Fishes, 30, 359-368.

Sayer, C. D. (2014). Conservation of aquatic landscapes: ponds, rivers and lakes as integrated systems. WIRE's Water, 1, 573-585.

Schmutz, S., Kremser, H., Melcher, A., Jungwirth, M., Muhar, S., Waidbacher, H., \& Zauner, G. (2014). Ecological effects of rehabilitation measures at the Austrian Danube: a meta-analysis of fish assemblages. Hydrobiologia, 729, 49-60.

Sear, D. A., Wilcock, D., Robinson, M. R., \& Fisher, K. R. (2000). Channel modifications and impacts. In M. C. Acreman (Ed.), The changing hydrology of the UK (pp. 55-81). London: Routledge.

Smith, E. P. (2002). BACI design. In: El-Shaarawi AH, Piegorsch WW, eds. Encyclopedia of Environmetrics, Vol. 1. John Wiley and Sons: Oxford; 141-148.

Smith, M. A. (2013). Outcomes of River Rehabilitation on Instream Hydraulics and Fish Communities. PhD Thesis. Hull: The University of Hull. 217 p. 
J. D. Champkin et al.

518 Solimini, A. G., Cardoso, A. C., \& Heiskanen, A. (2006). Indicators and methods for the ecological

519 status assessment under the Water Framework Directive: Linkages between chemical and

520 biological quality of surface waters. Joint Research Centre, European Commission: Brussels.

521 Stakènas, S., Vilizzi, L., \& Copp, G. H. (2013). Habitat use, home range, movements and

522 interactions of introduced Lepomis gibbosus and native Salmo trutta in a small stream of

Swales, S., \& O'Hara, K. (1983). A short-term study of the effects of a habitat improvement programme on the distribution and abundance of fish stocks in a small lowland river in Shropshire. Aquaculture Research, 14, 135-144.

Swales, S. (1988). Fish populations of a small lowland channelized river in England subject to long term river maintenance and management works. Regulated Rivers: Research and Management, 2, 493-506.

Theiling, C. H., Tucker, J. K., \& Cronin, F. A. (1999). Flooding and fish diversity in a reclaimed river-wetland. Journal of Freshwater Ecology, 14, 469-475.

Van Ginneken, V. .J. T., \& Maes, G. E. (2005). The European eel (Anguilla anguilla, Linnaeus), its lifecycle, evolution and reproduction: a literature review. Reviews in Fish Biology and Fisheries, $15,367-398$.

Zięba, G., Stakėnas, S., Godard, M. J., Ives, M., Seymour, J., Carter, M. G., \& Copp, G. H. (2014). Long-term decline of barbel Barbus barbus in a highly urbanised river of southeastern England, 


\section{RIPARIAN REHABILITATION IMPACTS ON FISH SPECIES}

542 with particular reference to the survival and movements of tagged fish during a water pollution 543 incident. Fundamental \& Applied Limnology, 185, 43-53.

544 Zika, U., \& Peter, A. (2002). The introduction of woody debris into a channelized stream: Effect on $545 \quad$ trout populations and habitat. River Research and Applications, 18, 355-366.

546

547

548

549

550

551

552

553

554

555

556

557

558

\section{ELECTRONIC REFERENCES}

European Parliament. (2000). Directive 2000/60/EC of the European Parliament and of the Council establishing a framework for the Community action in the field of water policy. Available at: http://eur-lex.europa.eu/LexUriServ/ LexUriServ.do?uri=CELEX:32000L0060:EN:NOT.

Herts and Middlesex Wildlife Trust. (2015). Living Rivers - A Team Effort Part 1. www.hertswildlifetrust.org.uk/blog/livingrivers/2015/10/22/living-rivers-team-effort-part-1

Scarlett, P., \& O'Hare, M. (2006). Integrated fisheries, RHS and ecological data model for the River Lee. Report to Environment Agency NE Thames Area (CEH Project No: C01019). Centre for Ecology and Hydrology, Winfrith, Dorset. (http://nora.nerc.ac.uk/3387/1/N003387CR.pdf)

Schwartz, C. J. (2014). Chapter 13: Analysis of BACI Experiments. In: Course notes for Beginning and Intermediate Statistics. Available at: www.stat.sfu.ca/ cschwarz/CourseNotes. 
J. D. Champkin et al.

559 Table 1. Number of fishes and lamprey sampled from two reaches (control, treatment) of the River Glaven 560 (North Norfolk, England) from 2009 to 2014 before (three sampling events) and after (four sampling events)

561 rehabilitation of the downstream reach

\begin{tabular}{ccrrrrrrr}
\hline Reach/Period & Event & $\begin{array}{r}\text { Anquilla } \\
\text { anguilla }\end{array}$ & $\begin{array}{r}\text { Cottus } \\
\text { gobio }\end{array}$ & $\begin{array}{r}\text { Esox } \\
\text { lucius }\end{array}$ & $\begin{array}{r}\text { Gasterosteus } \\
\text { aculeatus }\end{array}$ & $\begin{array}{r}\text { Lampetra } \\
\text { planeri }\end{array}$ & $\begin{array}{r}\text { Salmo } \\
\text { trutta }\end{array}$ & $\begin{array}{c}\text { Tinca } \\
\text { tinca }\end{array}$ \\
\hline Control & & & & & & & & \\
$\quad$ Before & 1 & 38 & 128 & 0 & 9 & 55 & 39 & 0 \\
Before & 2 & 30 & 62 & 0 & 5 & 96 & 32 & 0 \\
Before & 3 & 38 & 184 & 2 & 8 & 136 & 82 & 0 \\
After & 4 & 17 & 188 & 0 & 14 & 49 & 20 & 0 \\
After & 5 & 15 & 176 & 0 & 10 & 40 & 5 & 0 \\
After & 6 & 10 & 87 & 0 & 39 & 612 & 36 & 0 \\
After & 7 & 6 & 158 & 1 & 34 & 117 & 54 & 0 \\
Treatment & & & & & & & & \\
Before & 1 & 81 & 970 & 3 & 23 & 94 & 57 & 0 \\
Before & 2 & 87 & 680 & 0 & 41 & 127 & 63 & 0 \\
Before & 3 & 56 & 568 & 4 & 54 & 98 & 101 & 0 \\
After & 4 & 18 & 253 & 4 & 25 & 43 & 38 & 0 \\
After & 5 & 26 & 788 & 1 & 81 & 240 & 22 & 0 \\
After & 6 & 34 & 407 & 0 & 158 & 460 & 51 & 0 \\
After & 7 & 32 & 262 & 3 & 19 & 53 & 106 & 1 \\
& Total & $\mathbf{4 8 8}$ & $\mathbf{4 9 1 1}$ & $\mathbf{1 8}$ & $\mathbf{5 2 0}$ & $\mathbf{2 2 2 0}$ & $\mathbf{7 0 6}$ & $\mathbf{1}$ \\
\hline
\end{tabular}


Table 2. Before-After-Control-Impact (BACI) results for species-specific changes in five response variables measuring ichthyofauna structure in the River Glaven before and after (Period) rehabilitation in a downstream reach (treatment site) of the river relative to its upstream reach (control site). For heuristic purposes, the significance (in bold) of the relevant BACI contrast (Site $\times$ Period interaction term) is evaluated at $\alpha=0.10$ (see text for details)

\begin{tabular}{|c|c|c|c|c|c|c|c|c|c|c|}
\hline \multirow[b]{2}{*}{ Source of variation } & \multicolumn{2}{|c|}{ Anguilla anguilla } & \multicolumn{2}{|c|}{ Cottus gobio } & \multicolumn{2}{|c|}{ Gasterosteus aculeatus } & \multicolumn{2}{|c|}{ Lampetra planeri } & \multicolumn{2}{|c|}{ Salmo trutta } \\
\hline & $F$ & $P$ & $F$ & $P$ & $F$ & $P$ & $F$ & $P$ & $F$ & $P$ \\
\hline \multicolumn{11}{|l|}{ Abundance } \\
\hline (Intercept) & 209.40 & $<0.001$ & 59.84 & $<0.001$ & 12.25 & 0.017 & 5.70 & 0.063 & 24.04 & 0.004 \\
\hline Site & 28.49 & 0.003 & 21.52 & 0.006 & 4.97 & 0.076 & $<0.01$ & 0.976 & 419.74 & 0.007 \\
\hline Period & 52.44 & $<0.001$ & 2.41 & 0.182 & 1.27 & 0.311 & 0.56 & 0.487 & 1.01 & 0.362 \\
\hline Site $\times$ Period & 5.99 & 0.058 & 3.43 & 0.123 & 0.16 & 0.708 & 0.03 & 0.866 & 0.07 & 0.808 \\
\hline \multicolumn{11}{|l|}{ Length } \\
\hline (Intercept) & 714.11 & $<0.001$ & 1509.85 & $<0.001$ & 1550.66 & $<0.001$ & 2639.64 & $<0.001$ & 231.99 & $<0.001$ \\
\hline Site & 0.67 & 0.449 & 4.30 & 0.093 & 1.94 & 0.223 & 27.47 & 0.003 & 6.14 & 0.056 \\
\hline Period & 3.278 & 0.130 & $<0.01$ & 0.968 & 1.28 & 0.310 & 10.62 & 0.022 & 2.32 & 0.188 \\
\hline Site $\times$ Period & 0.04 & 0.843 & 1.07 & 0.348 & 3.09 & 0.139 & 1.65 & 0.255 & 2.92 & 0.148 \\
\hline \multicolumn{11}{|l|}{ Weight } \\
\hline (Intercept) & 50.66 & $<0.001$ & 180.52 & $<0.001$ & 441.54 & $<0.001$ & 457.79 & $<0.001$ & 54.78 & $<0.001$ \\
\hline Site & 4.92 & 0.077 & 3.95 & 0.103 & 1.60 & 0.262 & 47.27 & 0.001 & 7.02 & 0.045 \\
\hline Period & 1.58 & 0.265 & 0.02 & 0.897 & 1.27 & 0.312 & 14.80 & 0.012 & 5.60 & 0.064 \\
\hline Site $\times$ Period & 0.11 & 0.749 & 0.73 & 0.431 & 3.28 & 0.131 & 0.29 & 0.616 & 4.20 & 0.096 \\
\hline \multicolumn{11}{|l|}{ Biomass } \\
\hline (Intercept) & 66.76 & $<0.001$ & 54.08 & $<0.001$ & 13.35 & 0.015 & - & - & 15.41 & 0.011 \\
\hline Site & 0.66 & 0.454 & 2.10 & 0.207 & 0.02 & 0.908 & - & - & 0.60 & 0.475 \\
\hline Period & 2.14 & 0.203 & 0.68 & 0.448 & 2.55 & 0.171 & - & - & 0.26 & 0.633 \\
\hline Site $\times$ Period & 0.24 & 0.648 & 1.40 & 0.289 & 1.18 & 0.327 & - & - & 15.63 & 0.011 \\
\hline \multicolumn{11}{|l|}{ Density } \\
\hline (Intercept) & 104.80 & $<0.001$ & 42.10 & 0.001 & 12.49 & 0.017 & - & - & 29.14 & 0.003 \\
\hline Site & 0.01 & 0.911 & 2.88 & 0.150 & 0.09 & 0.771 & - & - & 4.13 & 0.098 \\
\hline Period & 22.53 & 0.005 & 0.19 & 0.682 & 2.17 & 0.200 & - & - & 1.13 & 0.337 \\
\hline Site $\times$ Period & 0.16 & 0.706 & 0.86 & 0.396 & 0.41 & 0.550 & - & - & 2.84 & 0.152 \\
\hline
\end{tabular}

25 
566

567

Figure 1. Site map showing the River Glaven at Hunworth (North Norfolk, eastern England), including the control and treatment reaches used in this study.

Figure 2. Re-meandered reach of the River Glaven at Hunworth (North Norfolk, UK): (a) in January 2009, prior to the rehabilitation project; (b) after removal of embankments in March 2009; and (c) in December 2010, after recreation of meanders in August. (d) Arc-GIS drawing of the original and re-meandered river channel.

Figure 3. Substratum ( $\% \pm$ S.E., top) and meso-habitat ( $\%$, bottom) composition of two reaches of the River Glaven at Hunworth, before (2009) and after (2012) re-meandering of the downstream (treatment) reach. Asterisks denote where statistically significant changes have occurred between 2009 and $2012(* * *=$ significant at $P<0.001 ; *=$ significant at $P<0.05 ; n=$ number of transects).

Figure 4. Species-specific changes in five response variables measuring fish community structure in the River Glaven before (three sampling events) and after (four sampling events) re-meandering of a downstream (treatment) reach relative to its the unmodified (control) reach. Solid line $=$ treatment site; dashed line $=$ control site. For abundance, length and weight, sample replicates (electrofishing runs) are indicated by dots (black $=$ treatment site; grey $=$ control site). For standing crop and density, 95\% confidence intervals are provided. Statistically significant BACI contrasts (Site $\times$ Period interaction term) for any species $\times$ variable combination highlighted in grey (see also Table 2). 


3
-3

$\times 3$
4
4
4
4
4
4
4
3
4
4
4
4
4
4
4
4
4

$\sqrt{4}$

4
4

4
5

5

5

53

5

5

5
5

5

$\frac{5}{6}$
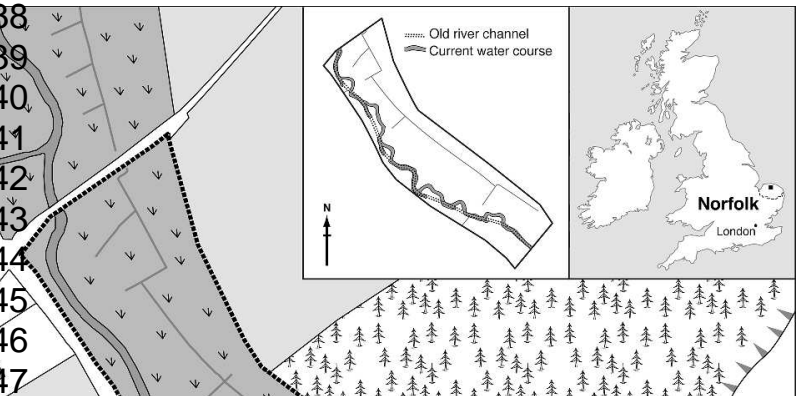

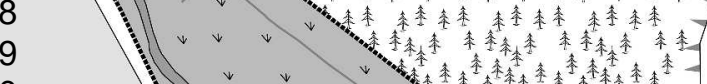

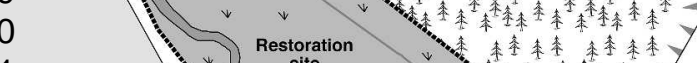

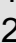
(n) 54 56 57 $\frac{6}{2}$ $\overline{5}$

9 EA gauging statio Road / track Control site Meadow 
a)

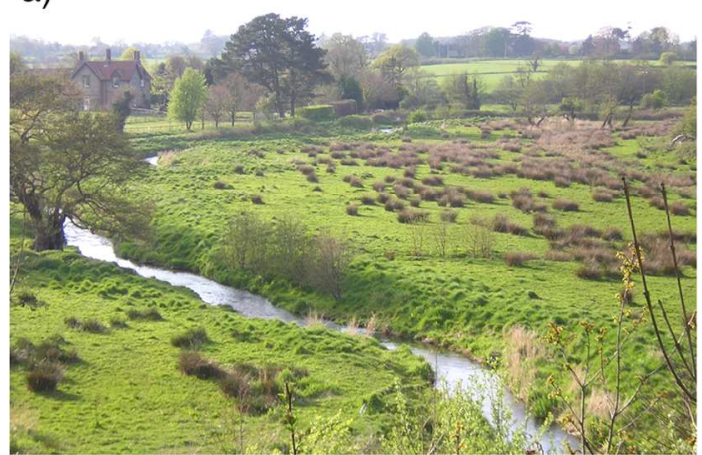

b)
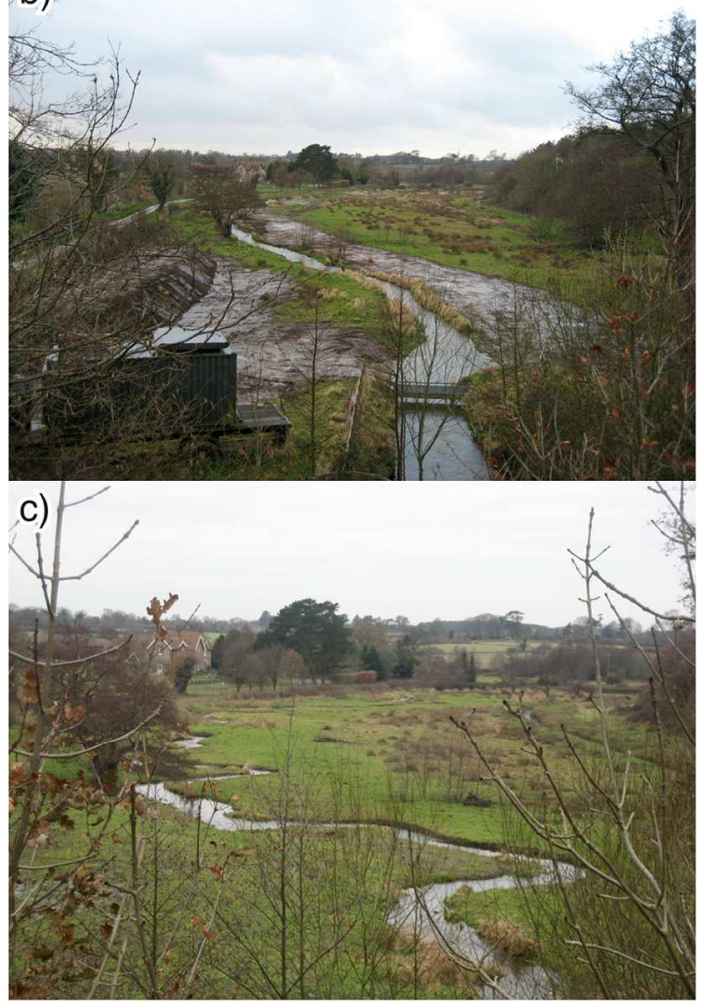

Figure 2. Re-meandered reach of the River Glaven at Hunworth (north Norfolk, UK): (a) in January 2009, prior to the rehabilitation project; (b) after removal of embankments in March 2009; and (c) in December 2010, after recreation of meanders in August. (d) Arc-GIS drawing of the original and re-meandered river channel.

$74 \times 169 \mathrm{~mm}(300 \times 300 \mathrm{DPI})$ 

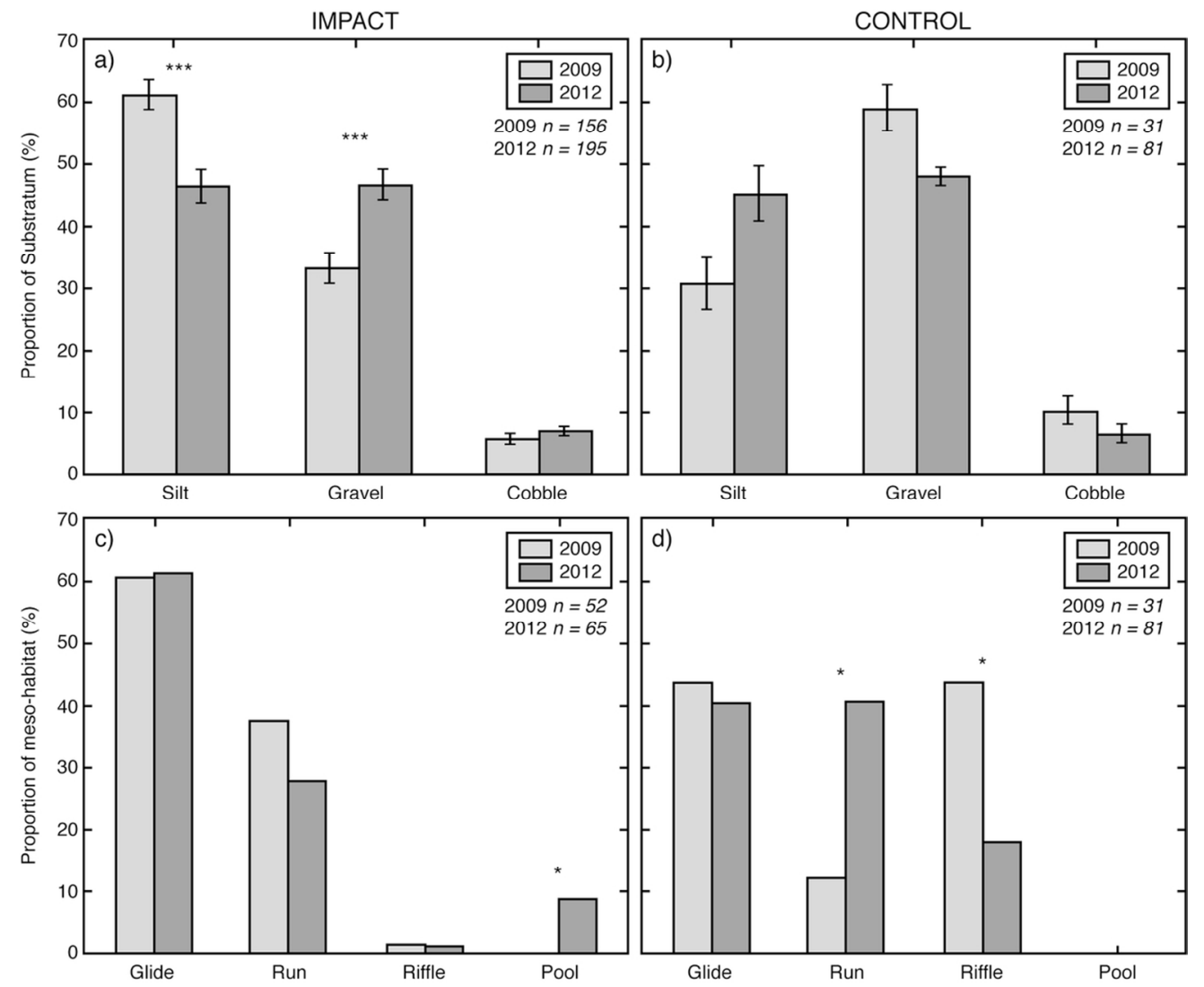

Figure 3: Substratum ( $\% \pm$ S.E., top) and meso-habitat (\%, bottom) composition of two reaches of the River Glaven at Hunworth, before (2009) and after (2012) re-meandering of the downstream (treatment) reach. Asterisks denote where statistically significant changes have occurred between 2009 and 2012 (*** $=$ significant at $\mathrm{P}<0.001 ; *=$ significant at $\mathrm{P}<0.05 ; \mathrm{n}=$ number of transects).

\section{$106 \times 89 \mathrm{~mm}(300 \times 300 \mathrm{DPI})$}


Anguilla anguilla River Research and Applfentibtus gobio
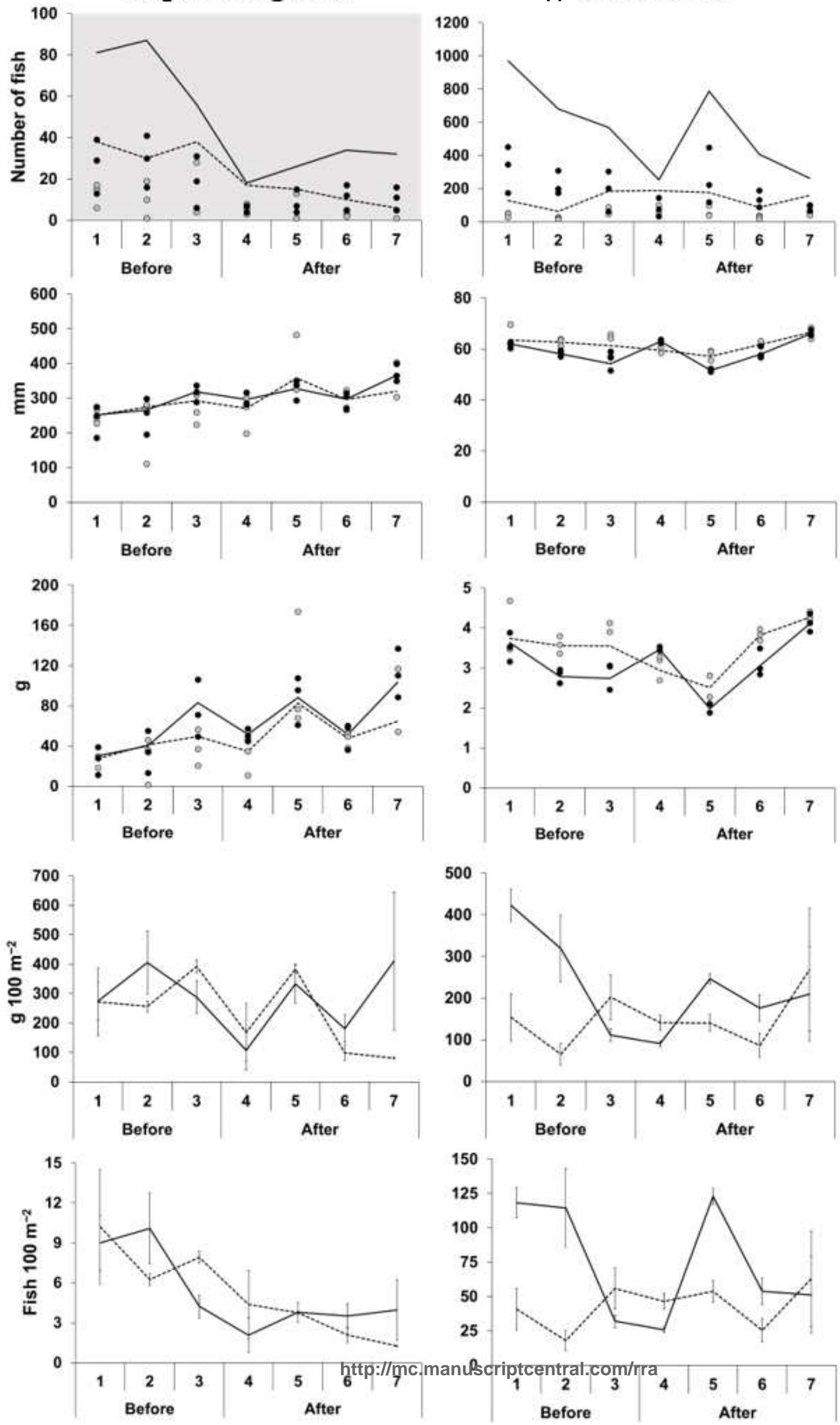
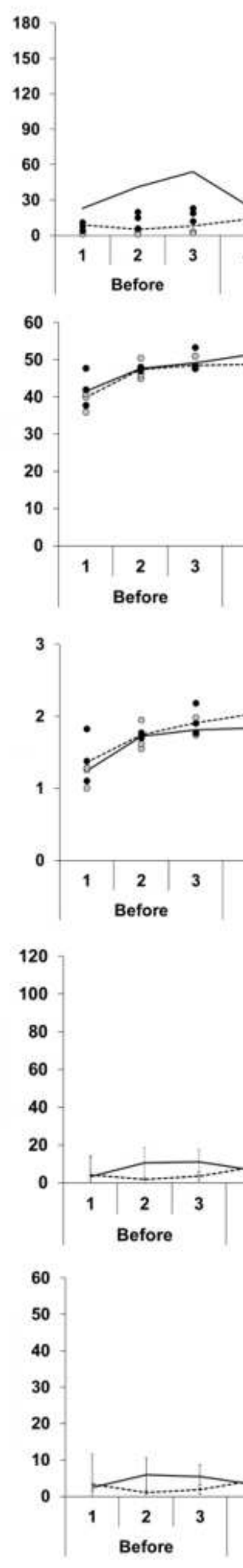